\title{
Rada Gabinetowa w Polsce
}

\author{
Dariusz Górecki \\ Uniwersytet Łódzki, Wydział Prawa i Administracji \\ Katedra Prawa Konstytucyjnego
}

\section{Wprowadzenie}

Przyjęcie w Konstytucji RP z 2 kwietnia 1997 r. ${ }^{1}$ dwuczłonowego modelu władzy wykonawczej, poprzez zaliczenie do niej obok Rady Ministrów także prezydenta, postawiło przed jej twórcami konieczność wypracowania płaszczyzny współpracy między nimi. W tym celu posłużono się instytucją Rady Gabinetowej, składającej się z Rady Ministrów obradującej pod przewodnictwem prezydenta. Przy okazji warto zauważyć, że jest to rozwiązanie analogiczne do regulacji odnoszącej się do legislatywy. Tam formą wspólnej pracy dwu organów władzy ustawodawczej - Sejmu i Senatu, przewidzianej dla spraw ściśle określonych w konstytucji, jest Zgromadzenie Narodowe ${ }^{2}$. Podobnie Rada Gabinetowa nie spełnia kryteriów pozwalających na uznanie jej za organ państwowy.

Przegląd konstytucji republik europejskich ukazuje, że niektóre z nich przewidują występowanie instytucji integrujących obydwa segmenty władzy wykonawczej: prezydenta i rządu. W półprezydenckim systemie we Francji głowa państwa przewodniczy posiedzeniom Rady Ministrów (art. 9)³, w Rosji „ma prawo” im przewodniczyć (art. 83 ust. 1 lit. b) ${ }^{4}$, podobnie na Białorusi (art. 84 pkt 15) ${ }^{5}$. Również w Portugalii prezydent może przewodniczyć posiedzeniu Rady Ministrów, „jeżeli premier o to wystąpi” (art. 133 ust. 1 lit. i) ${ }^{6}$. Podobne rozwiązanie przyjęto w Rumunii - tam bowiem prezydent może uczestniczyć w posiedzeniach rządowych i przewodniczyć im w sprawach wymienionych w konstytucji oraz na

1 Dz.U. z 1997 r., nr 78, poz. 483 ze zm.

2 Szerzej: D. Górecki, Uwagi o charakterze Zgromadzenia Narodowego, [w:] M. Zubik (red.), Minikomentarz dla maksiprofesora. Księga jubileuszowa Profesora Leszka Garlickiego, Warszawa 2017, s. 480-488. Konstytucja Republiki Francuskiej z 4 października 1958 r., tłum. W. Skrzydło, Warszawa 2000.

4 Konstytucja Federacji Rosyjskiej z 12 grudnia 1993 r., tłum. A. Kubik, Warszawa 2000.

5 Konstytucja Republiki Białorusi z 15 marca 1996 r., https://en.wikisource.org/wiki/Constitution.of.the.Republic.of.Belarus (dostęp: 11.02.2014).

6 Konstytucja Republiki Portugalskiej z 2 kwietnia 1976 r., tłum. A. Wojtyczek-Bonnand, Warszawa 2000. 
wniosek premiera „w innych sytuacjach” (art. 87) ${ }^{7}$. Prowadzenie „nadzwyczajnych posiedzeń" rządu przewiduje konstytucja Łotwy (art. 46) ${ }^{8}$. Przewodnictwo prezydenta na posiedzeniach Rady Państwa (rządu) przewidują konstytucje Islandii $(\text { art. } 16)^{9}$ i Finlandii $(\$ 58)^{10}$. Natomiast ustawy zasadnicze niektórych państw zakładają inne formy współpracy: w Chorwacji prezydent może wnosić o zwołanie posiedzenia rządu „w celu rozpatrzenia określonych spraw” oraz „brać udział w obradach" (art. 101) ${ }^{11}$, natomiast w Czechach może uczestniczyć w posiedzeniach rządu, a także żądać od niego i jego członków informacji oraz omawiać z nimi zagadnienia należące do zakresu ich działania (art. 64) ${ }^{12}$. Prawo prezydenta do żądania od rządu i jego członków informacji potrzebnych dla wykonywania swych kompetencji przewiduje też konstytucja Słowacji (art. 102 ust. 1 lit. r) ${ }^{13}$.

Zagadnienie wzajemnego oddziaływania głowy państwa i rządu, poza sytuacjami wymuszonymi konstytucyjnie (powoływanie rządu, kontrasygnowanie aktów prezydenta), nie było uregulowane w obu polskich konstytucjach międzywojennych. W praktyce pojawiły się jednak pewne formy ich wzajemnego oddziaływania. W okresie obowiązywania Konstytucji RP z 17 marca 1921 r. ${ }^{14}$ prezydent sporadycznie uczestniczył w posiedzeniach Komitetu Politycznego Ministrów, a nawet Rady Ministrów ${ }^{15}$. Z kolei w czasie obowiązywania ustawy konstytucyjnej z 23 kwietnia $1935 \mathrm{r}^{16}$ prezydent również rzadko uczestniczył w posiedzeniach Rady Ministrów, lecz odbywał cotygodniowe spotkania z premierem. Z reguły uczestniczył $\mathrm{w}$ nich wicepremier, a czasem minister spraw zagranicznych. Prezydent spotykał się również z poszczególnymi członkami gabinetu. Sporadycznie odbywał też narady polityczne z udziałem wszystkich członków rządu ${ }^{17}$. Bezpośrednie kontakty prezydenta $\mathrm{z}$ członkami rządu były kontynuowane w warunkach emigracyjnych ${ }^{18}$.

7 Konstytucja Rumunii z 21 listopada 1991 r., tłum. A. Cosma, Warszawa 1996.

8 Konstytucja Republiki Łotewskiej z 15 lutego 1922 r., tłum. L. Gołupiec, Warszawa 2001.

9 Konstytucja Republiki Islandii z 17 czerwca 1944 r., tłum. J. Osiński, Warszawa 2009.

10 Konstytucja Republiki Finlandii z 11 czerwca 1999 r., tłum. J. Osiński, Warszawa 2003.

11 Konstytucja Republiki Chorwacji z 22 grudnia 1990 r., tłum. T. Wójcik, M. Petryńska, Warszawa 2007.

12 Konstytucja Republiki Czeskiej z 16 grudnia 1992 r., tłum. K. Skotnicki, Łódź 1994.

13 Konstytucja Republiki Słowackiej z 1 września 1992 r., tłum. K. Skotnicki, Warszawa 2003.

14 Dz.U. z 1921 r., nr 44, poz. 267 ze zm.

15 Z. Witkowski, Prezydent Rzeczypospolitej Polskiej 1921-1935, Warszawa-Poznań-Toruń 1987, s. 116, 155, 156; A. Garlicki, Józef Piłsudski 1867-1935, Warszawa 1990, s. 337.

16 Dz.U. z 1935 r., $\mathrm{nr}$ 30, poz. 227.

17 D. Górecki, Pozycja ustrojowo-prawna Prezydenta Rzeczypospolitej i rzqdu w ustawie konstytucyjnej z 23 kwietnia 1935 roku, Łódź 1995, s. 79, 80.

18 D. Górecki, Polskie naczelne władze państwowe na uchodźstwie w latach 1939-1990, Warszawa 2002. 


\section{Ewolucja Rady Gabinetowej w Polsce}

Instytucja Rady Gabinetowej pojawiła się w Polsce w ustawie konstytucyjnej z 19 lutego 1947 r. o organizacji i zakresie działania najwyższych organów Rzeczypospolitej Polskiej (tzw. Małej Konstytucji) ${ }^{19}$. Zgodnie z jej art. 18 Radę Gabinetową „dla rozpatrzenia spraw szczególnej wagi” zwoływał premier na życzenie prezydenta. Stanowiła ona Radę Ministrów obradującą pod przewodnictwem prezydenta. Według twórców Małej Konstytucji Rada Gabinetowa miała być zwoływana rzadko, skoro jej przedmiotem miały być sprawy jedynie „szczególnej wagi”. Wprawdzie premier był jedynym podmiotem upoważnionym do jej zwołania, to jednak sam nie posiadał inicjatywy w tym zakresie. Premier nie mógł odmówić życzeniu prezydenta. Wskazuje na to wyraźnie sformułowanie zastosowane w art. 18 ust. 1: premier „zwołuje” Radę Gabinetową, a nie „może zwołać”. Ograniczenie głowy państwa do wnioskowania o zwołanie jej posiedzenia dla spraw „szczególnej wagi” było ograniczeniem formalnym, niemającym w rzeczywistości większego znaczenia. Ostatecznie to prezydent decydował o uznaniu sprawy za szczególnie ważną.

Niestety, Mała Konstytucja nie określała, czym miały kończyć się obrady Rady Gabinetowej, a w szczególności czy mogła przejmować kompetencje Rady Ministrów ${ }^{20}$. W literaturze wyrażony jest pogląd, że skoro tworzył ją organ mający rozległe kompetencje, jakim jest Rada Ministrów, tyle że obradowała pod przewodnictwem prezydenta, to wobec braku zastrzeżenia ze strony ustawodawcy o ograniczeniu jej uprawnień należy uznać, że Rada Gabinetowa mogła podejmować decyzje o wiążącym charakterze ${ }^{21}$. Wprawdzie Rada Gabinetowa w tym okresie nigdy nie została zwołana, to jednak uwzględniając fakt, że prezydent stał jednocześnie na czele partii komunistycznej (Polskiej Partii Robotniczej, później Polskiej Zjednoczonej Partii Robotniczej), sprawującej kierowniczą rolę w państwie, ewentualna praktyka z pewnością potwierdziłaby tę tezę.

Na podstawie nieopublikowanej uchwały Rady Ministrów z 31 maja 1950 r. zostało utworzone pozakonstytucyjne Prezydium Rządu. Jego zadaniem było kierowanie pracami rządu we wszystkich działach jego kompetencji ${ }^{22}$. Skład Prezydium Rządu tworzyli: prezydent, premier, jego zastępcy i podsekretarz stanu w Prezydium Rady Ministrów. Ponadto na wniosek premiera prezydent mógł powołać do jego składu innych członków gabinetu. Prezydium Rządu zbierało się systematycz-

19 Dz.U. z 1947 r., nr 18, poz. 71 ze zm.

20 W. Skrzydło, Instytucja Rady Gabinetowej w Polsce, [w:] A. Łopatka, A. Wróbel, S. Kiewlicz (red.), Państwo prawa, administracja, sq̨downictwo, Warszawa 1999, s. 147.

21 B. Opaliński, Rozdzielenie kompetencji władzy wykonawczej między Prezydenta RP oraz Radę Ministrów na tle Konstytucji Rzeczypospolitej Polskiej z 1997 roku, Warszawa 2012, s. 324.

22 S. Rozmaryn, Polskie prawo państwowe, Warszawa 1951, s. 462; Z. Jarosz, Rozwój ustroju państwowego Polski Ludowej w latach 1944-1952, [w:] Z. Jarosz, S. Zawadzki, Prawo konstytucyjne, Warszawa 1980, s. 63. 
nie i dlatego nie można uznać go za sui generis Radę Gabinetową, skoro ta miała zajmować się tylko sprawami wagi wyjątkowej. Różny też był ich skład osobowy. W każdym razie Prezydium Rządu niewątpliwie zapewniło prezydentowi realny wpływ na działalność Rady Ministrów.

Likwidacja instytucji prezydenta w Konstytucji Polskiej Rzeczypospolitej Ludowej z 22 lipca 1952 r. ${ }^{23}$ i zastąpienie jej przez Radę Państwa czyniło bezprzedmiotowym dalsze utrzymanie Rady Gabinetowej. O przywróceniu instytucji jednoosobowej głowy państwa zadecydowały ustalenia zawarte podczas obrad Okrągłego Stołu. Uzgodniono wówczas, że prezydentem zostanie komunista, który kilka lat wcześniej zapowiadał, że socjalizmu będzie bronił jak niepodległości. W dwa dni po zakończeniu obrad ustalenia te zyskały rangę konstytucyjną - w dniu 7 kwietnia 1989 r. uchwalono ustawę o zmianie Konstytucji Polskiej Rzeczypospolitej Ludowej $^{24}$. Według jej postanowień prezydent został wyposażony w bardzo istotne prerogatywy. Miały zapewnić mu możliwość realnego wpływu na sytuację w państwie i czyniły go gwarantem utrzymania osiągniętego kompromisu politycznego.

W uchwalonym wówczas art. $32 \mathrm{f}$ ust. 1 pkt 8 Konstytucji przyznano prezydentowi prawo zwoływania „w sprawach szczególnej wagi” posiedzeń Rady Ministrów i przewodniczenia im. Różnica w porównaniu do jego uprawnień w Radzie Gabinetowej z Małej Konstytucji z 1947 r. była niewielka - to nie premier, lecz prezydent uzyskał prawo do zwoływania tych posiedzeń. Pozostałe regulacje utrzymano takie same. Ograniczenie przedmiotu obrad do spraw „szczególnej wagi” zdaniem niektórych przedstawicieli doktryny można tłumaczyć tym, że ustawodawca zakładał „wyraźnie samodzielność działania rządu” i liczył na „powściągliwość” prezydenta w korzystaniu z tej kompetencjii ${ }^{25}$. Praktyka wydaje się potwierdzać słuszność tej tezy. Wojciech Jaruzelski ani razu nie skorzystał z tego uprawnienia. Natomiast Lech Wałęsa po raz pierwszy 13 lutego 1992 r. wziął udział w posiedzeniu prezydium rządu, lecz nie całej Rady Ministrów. Wkrótce, bo 3 marca, przybył na posiedzenie rządu poświęcone sprawom bezpieczeństwa i obronności kraju. W obydwu wypadkach prezydent jednak tych posiedzeń nie zwoływał i im nie przewodniczy1 ${ }^{26}$.

Wprawdzie obaj pierwsi prezydenci ani razu formalnie nie zwołali posiedzenia Rady Ministrów, jednak przypisywanie ustrojodawcy intencji, aby art. 32f ust. 1 pkt 8 odczytywać jako liczenie na powściągliwość głowy państwa w zwoływaniu posiedzeń Rady Ministrów, mimo potwierdzenia w praktyce, wcale nie musiało tego oznaczać. Przecież w okresie transformacji ustrojowej niewątpliwie wiele

23 Dz.U. z 1952 r., nr 33, poz. 232 ze zm.

24 Dz.U. z 1989 r., nr 19, poz. 101.

25 T. Szymczak, Instytucja Prezydenta RP według noweli kwietniowej i w praktyce, „Państwo i Prawo" 1990, z. 10, s. 15.

26 T. Szymczak, Prezydent Rzeczypospolitej Polskiej, [w:] T. Szymczak (red.), Materiały pomocnicze do nauki prawa konstytucyjnego (1980-1991), Łódź 1992, s. 43. 
działań podejmowanych przez rząd było szczególnej wagi państwowej, uzasadniających ewentualne zwołanie posiedzenia Rady Ministrów przez prezydenta ${ }^{27}$.

Przepis art. $32 \mathrm{f}$ ust. 1 pkt 8 prawie w niezmienionym kształcie został powtórzony w art. 38 ust. 2 ustawy konstytucyjnej z 17 października 1992 r. o wzajemnych stosunkach między władzą ustawodawczą i wykonawczą Rzeczypospolitej Polskiej oraz o samorządzie terytorialnym (tzw. Mała Konstytucja) ${ }^{28}$. Ponadto art. 38 ust. 1 nakładał na premiera obowiązek informowania prezydenta o podstawowych problemach będących przedmiotem pracy Rady Ministrów.

Rozwiązania przyjęte w art. 38 ust. 2 Małej Konstytucji wynikały z potrzeby stworzenia podstaw prawnych dla aktywnej prezydentury, a ograniczenie przedmiotu obrad Rady Ministrów do spraw szczególnej wagi nie musiało oznaczać powściągliwości głowy państwa do zwoływania jej posiedzeń. Zdaniem Ryszarda Mojaka korzystanie z tych uprawnień mogło w znacznym stopniu przyczynić się do nadania polskiej prezydenturze „modelu ustrojowego zbliżonego do wzorów francuskich"29. Było to tym bardziej prawdopodobne, że (podobnie jak w okresie poprzednim) decyzje podejmowane na posiedzeniu gabinetu pod przewodnictwem prezydenta były wiążące $\mathrm{w}$ takim samym stopniu, jak na posiedzeniach pod przewodnictwem premiera ${ }^{30}$.

Pomimo przyznania prezydentowi w art. 38 ust. 2 możliwości bezpośredniego wpływania na decyzje rządowe, Lech Wałęsa nie korzystał z prawa zwoływania posiedzeń Rady Ministrów. Inaczej pojmował on swoją rolę ustrojową, widząc siebie jako samodzielny czynnik władzy wykonawczej. Prezydent włączał się więc w prace rządowe, ale w innej formie - uczestniczył w posiedzeniach Prezydium Rządu i Rady Ministrów. Prowadziło to wielokrotnie do konfrontacji konstytucyjnej władzy głowy państwa z praktyką ustrojową ${ }^{31}$.

\section{Rada Gabinetowa w Konstytucji RP z 1997 r.}

Przygotowując tekst Konstytucji RP z 2 kwietnia 1997 r., jej twórcy musieli uwzględnić doświadczenia płynące $\mathrm{z}$ wcześniejszej praktyki ustrojowej i obowiązujących wówczas uregulowań prawnych. Przyjęte rozwiązania poszły w kie-

27 R. Mojak, Instytucja Prezydenta RP w okresie przeksztatceń ustrojowych 1989-1992, Warszawa 1994, s. 235; W. Skrzydło, Instytucja Rady Gabinetowej..., s. 148.

28 Dz.U. z 1992 r., nr 84, poz. 426 ze zm.

29 R. Mojak, Prezydent Rzeczypospolitej Polskiej, [w:] W. Skrzydło (red.), Prawo konstytucyjne, Lublin 1996, s. 294.

30 R. Glajcar, Relacje prezydenta z Radq Ministrów, [w:] R. Glajcar, M. Migalski (red.), Prezydent w Polsce po 1989 r. Studium politologiczne, Warszawa 2006, s. 135.

31 R. Mojak, Instytucja Prezydenta RP..., s. 236. 
runku osłabienia pozycji prezydenta w odniesieniu do jego stosunków z rządem. Zgodnie z art. 141 Konstytucji prezydent może w sprawach „szczególnej wagi” zwołać Radę Gabinetową, którą tworzy Rada Ministrów obradująca pod przewodnictwem głowy państwa. Konstytucja jednak wyraźnie stanowi, że Radzie Gabinetowej nie przysługują kompetencje Rady Ministrów. Wprawdzie Konstytucja na ten temat milczy, ale oczywiste jest, że nie przysługują jej także uprawnienia głowy państwa.

Sformułowania nazywające posiedzenia rządowe pod przewodnictwem prezydenta Radą Gabinetową, zastosowane w art. 141, formalnie nawiązują do Małej Konstytucji z 1947 r. O ile jednak takie posiedzenia na gruncie rozwiązań z 1947, 1989 i 1992 r. mogły kończyć się podejmowaniem wiążących decyzji, o tyle obecna Konstytucja (art. 141 ust. 2) wyraźnie taką ewentualność wyklucza. Zatem wobec braku jakichkolwiek kompetencji nie można uznać Rady Gabinetowej za organ państwa. Jest ona wyłącznie forum dyskusyjnym, zapewniającym prezydentowi współdziałanie z rządem ${ }^{32}$. Wprawdzie nie przysługują jej żadne kompetencje, jednak jej zwołanie jest wydarzeniem nagłaśnianym w środkach masowego przekazu, mającym duże znaczenie polityczne ${ }^{33}$. W literaturze podkreśla się, że sensem istnienia Rady Gabinetowej jest nadanie formalnych ram kontaktom między dwoma organami władzy wykonawczej oraz stworzenie płaszczyzny nie tylko umożliwiającej rozwiązywanie ewentualnych konfliktów między nimi, lecz także służącej wzajemnemu wyjaśnianiu swych stanowisk ${ }^{34}$. Wobec faktu, że ustawodawca konstytucyjny zrezygnował z obowiązku premiera informowania prezydenta o podstawowych problemach będących przedmiotem prac rządu (przewidzianego w art. 38 ust. 1 Małej Konstytucji z 1992 r.), wzrosło znaczenie Rady Gabinetowej jako źródła takich informacji ${ }^{35}$. Oczywiście obecny stan prawny nie wyklucza możliwości zapraszania prezydenta przez szefa rządu na niektóre posiedzenia Rady Ministrów ${ }^{36}$.

Fakt nieposiadania przez Radę Gabinetową kompetencji Rady Ministrów nie wyklucza możliwości podejmowania przez nią pewnych działań, będących następstwem dyskusji toczącej się na posiedzeniu Rady Gabinetowej. W ten sposób - jak

32 W. Skrzydło, Instytucja Rady Gabinetowej..., s. 150; R. Glajcar, Relacje prezydenta..., s. 136; P. Kierończyk, Rada Gabinetowa, [w:] A. Szmyt (red.), Leksykon prawa konstytucyjnego, Warszawa 2010, s. 446; S. Patyra, Pozycja ustrojowa i funkcje prezesa Rady Ministrów - założenia konstytucyjne a praktyka, [w:] M. Grzybowski (red.), System rzq̨dów Rzeczypospolitej Polskiej. Założenia konstytucyjne a praktyka ustrojowa, Warszawa 2006, s. 199; S. Patyra, Prawnoustrojowy status prezesa Rady Ministrów w świetle konstytucji z 2 kwietnia 1997 r., Warszawa 2002, s. 128.

33 P. Sarnecki, Prezydent Rzeczypospolitej Polskiej, Kraków 2000, s. 93.

34 B. Banaszak, Konstytucja Rzeczypospolitej Polskiej. Komentarz, Warszawa 2009, s. 683; B. Banaszak, Prawo konstytucyjne, Warszawa 2012, s. 507.

35 Brak wśród postanowień Konstytucji regulacji analogicznej do art. 38 ust. 1 Małej Konstytucji w literaturze określany jest wręcz jako „błąd ustrojodawcy”. T. Słomka, Prezydent Rzeczypospolitej po 1989 roku. Ujęcie porównawcze, Warszawa 2005, s. 249.

36 J. Ciapała, Prezydent w systemie ustrojowym Polski (1989-1991), Warszawa 1999, s. 299. 
zauważa Zbigniew Witkowski - prezydent staje się bardziej organem doradczym Rady Ministrów, a nie zwierzchnim wobec rządu ${ }^{37}$. Pogląd ten należy jednak uzupełnić - nie można przecież wykluczyć, że wyciągając wnioski z takiej dyskusji, również prezydent może podejmować pewne działania, a to oznaczałoby, że w takiej sytuacji Rada Gabinetowa stawałaby się sui generis doradcą głowy państwa. Niestety, dotychczasowa praktyka nie potwierdza powyższych spostrzeżeń. Rady Gabinetowe nie skutkowały realnymi konsekwencjami.

Zwoływanie posiedzeń Rady Gabinetowej jest prawem prezydenta, niewymagającym współdziałania z premierem. W Małej Konstytucji z 1947 r. Radę zwoływał premier, ale na wyłączny wniosek głowy państwa. Obecnie decyzja prezydenta zaliczona jest do jego prerogatyw niewymagających kontrasygnaty szefa rządu (art. 144 ust. 3 pkt 15 Konstytucji). Oczywiście, może się zdarzyć, że prezydent zwoła Radę Gabinetową na prośbę premiera. W takim wypadku i tak będzie to jego suwerenna decyzja. Za przykład może posłużyć zwołanie Rady w dniu 12 czerwca 2002 r. przez prezydenta Aleksandra Kwaśniewskiego na wniosek premiera Leszka Millera $^{38}$. Obaj jednak byli przedstawicielami tego samego nurtu politycznego. Natomiast zabiegi premier Ewy Kopacz o zwołanie Rady Gabinetowej przez prezydenta Andrzeja Dudę, zgłaszane w warunkach kohabitacji w okresie wyborów parlamentarnych w 2015 r. i na dzień przed zaprzysiężeniem prezydenta, zostały nieuwzględnione ${ }^{39}$. Występując $\mathrm{z}$ taką propozycją, premier miała nadzieję, że wpłynie to na zmianę preferencji wyborców.

Po wpłynięciu zawiadomienia prezydenta o zwołaniu posiedzenia Rady Gabinetowej premier, zgodnie z art. 19 ustawy z 8 sierpnia 1996 r. o organizacji i trybie pracy Rady Ministrów oraz zakresie działania ministrów, miał obowiązek niezwłocznego zawiadomienia o tym członków rządu ${ }^{40}$. Przepis ten jednak już nie obowiązuje, bowiem art. 8 pkt 3 ustawy z 24 lipca 1999 r. o zmianie ustawy o działach administracji rządowej oraz niektórych innych ustaw uchylił art. 19 przywołanej powyżej ustawy ${ }^{41}$. Zwoływanie Rady Gabinetowej należy więc do prezydenta, który powinien zaprosić na posiedzenie wszystkich członków rządu. Nie może więc dokonywać wśród nich żadnej selekcji ze względu na zagadnienia, które zamierza omówić. W czasie posiedzenia ministrowie zachowują wszystkie uprawnienia, jakie posiadają w trakcie posiedzeń rządowych, ponieważ Radę Gabine-

37 Z. Witkowski, Prezydent Rzeczypospolitej Polskiej, [w:] Z. Witkowski (red.), J. Galster et al., Prawo konstytucyjne, Toruń 2011, s. 382.

38 K. Leszczyńska, Rządy Rzeczypospolitej Polskiej (1989-2005). Skład, organizacja i tryb funkcjonowania, Toruń 2008, s. 412.

39 Kopacz prosi Dudę o zwołanie Rady Gabinetowej... a PiS proponuje premier „kawę, herbatę, a nawet obiad", http://wyborcza.pl/1,75398,18540082,kopacz-prosi-dude-o-zwolanie-rady-gabinetowej-a-pis-proponuje.html (dostęp: 7.09.2017).

40 Dz.U. z 1996 r., nr 106, poz. 492 ze zm.

41 Dz.U. z 1999 r., nr 70, poz. 778. 
tową "tworzy” Rada Ministrów ${ }^{42}$. Wprawdzie Konstytucja o tym nie przesądza, jednak w praktyce Rady Gabinetowe zwoływane są na posiedzenia jednodniowe. Wyjątek stanowi jej posiedzenie z 6 listopada 2002 r. poświęcone strategii rozwoju Polski po wejściu do Unii Europejskiej. Otóż, z inicjatywy prezydenta zostało ono przerwane z zapowiedzią, że będzie kontynuowane, chociaż bez podania terminu. Kontynuowano je 19 grudnia $2002 \mathrm{r}$.

Zagadnieniem budzącym wątpliwości w literaturze jest sprawa zwoływania posiedzeń Rady Gabinetowej przez Marszałka Sejmu (ewentualnie Marszałka Senatu) pełniącego tymczasowo obowiązki głowy państwa. Konstytucja w art. 131 ust. 4 stanowi, że osoba wykonująca obowiązki prezydenta nie może zadecydować o skróceniu kadencji Sejmu. Zdaniem większości przedstawicieli doktryny oznacza to, że może ona wykonywać wszystkie pozostałe kompetencje prezydenta. Natomiast według Dariusza Dudka w art. 131 jest mowa (sześciokrotnie) tylko o wykonywaniu obowiązków prezydenta, a nie o jego prawach i z tego względu Marszałek Sejmu (Senatu) nie może wykonywać żadnych kompetencji głowy państwa, które nie mają postaci ściśle pojmowanych obowiązków prawnych ${ }^{43}$. Pogląd ten podziela Bartłomiej Opaliński, odwołując się bezpośrednio do art. 141 ust. 1, stanowiącego, że prezydent „może” (a zatem nie musi) zwołać posiedzenie Rady Gabinetowej ${ }^{44}$.

Zwoływanie Rady Gabinetowej jest niewątpliwie prawem, a nie obowiązkiem głowy państwa. W praktyce powyższych zastrzeżeń nie podzielono. Wykonujący tymczasowo obowiązki prezydenta Marszałek Sejmu Bronisław Komorowski zwołał Radę Gabinetową w dniu 10 czerwca 2010 r. Przedmiotem obrad były problemy bezpieczeństwa państwa $\mathrm{w}$ obliczu zagrożenia powodziowego. Wydaje się jednak, że nie względy merytoryczne zadecydowały o zwołaniu jej posiedzenia. Biorąc pod uwagę, że posiedzenie Rady Gabinetowej odbyło się na 10 dni przed pierwszą turą wyborów prezydenckich, można uznać, iż było ono elementem kampanii wyborczej Marszałka Sejmu ubiegającego się o urząd prezydenta.

Kwestią w Konstytucji niesprecyzowaną, a w praktyce budzącą pewne kontrowersje jest udział w posiedzeniach Rady Gabinetowej osób niebędących członkami Rady Ministrów. Na przykład już w pierwszym posiedzeniu Rady Gabinetowej (27 stycznia 1998 r.) wzięli udział ministrowie z Kancelarii Prezydenta, a w drugim posiedzeniu (24 marca 1998 r.) oprócz sekretarzy stanu z Kancelarii Prezydenta uczestniczyli trzej sekretarze stanu z Kancelarii Prezesa Rady Ministrów, Rzecznik Prasowy Rządu i sekretarz Rady Ministrów. Z kolei gdy prezydent Aleksander Kwaśniewski zwołał Radę Gabinetową na 21 lutego 2002 r., premier Leszek

42 P. Sarnecki, Komentarz do art. 141, uwaga nr 3, [w:] L. Garlicki (red.), Konstytucja Rzeczypospolitej Polskiej. Komentarz, t. I, Warszawa 1999.

43 D. Dudek, Autorytet prezydenta a Konstytucja Rzeczypospolitej Polskiej, Lublin 2013, s. 42.

44 B. Opaliński, Rozdzielenie kompetencji..., s. 333. 
Miller zadecydował, że w posiedzeniu wezmą udział sekretarz Komitetu Integracji Europejskiej i szef Kancelarii Prezesa Rady Ministrów jako sekretarz Rady ze strony rządowej. Należy wszakże zauważyć, że na posiedzenie Rady Gabinetowej 12 czerwca 2002 r., zwołanej na wniosek premiera, nie został zaproszony prezes Narodowego Banku Polskiego Leszek Balcerowicz, gdyż prezydent uznał jego obecność za zbędnąa

Stanowisko prezydenta pozornie może wydawać się pozbawione konsekwencji, skoro wcześniej dopuszczał do uczestnictwa w posiedzeniach osoby postronne. Jednak zgodnie z Konstytucją to prezydent jest gospodarzem Rady Gabinetowej i do niego należy decyzja o uczestnictwie w posiedzeniu osób niebędących członkami rządu. Zagadnienie uczestnictwa w posiedzeniach Rady Gabinetowej osób spoza składu rządu powróciło w 2008 r. w warunkach kohabitacji. Prezydent Lech Kaczyński zadecydował wówczas o udziale w posiedzeniu prezesa Narodowego Banku Polskiego Sławomira Skrzypka, co było zaskoczeniem dla premiera Donalda Tuska i spowodowało półgodzinne opóźnienie rozpoczęcia obrad. Według Piotra Winczorka skład Rady Gabinetowej jest określony w ustawie zasadniczej i „dodatkowo nie należy nikogo do niej zapraszać”. Jego zdaniem jeśli zachodzi potrzeba jakichś uzgodnień z kimś spoza tego składu, to „są inne możliwości niż Rada Gabinetowa"46.

Stanowisko P. Winczorka trudno uznać za trafne. Zarówno praktyka wcześniejsza, jak i późniejsza dopuszczały udział w posiedzeniach Rady Gabinetowej osób niebędących członkami rządu. I nie dotyczyło to wyłącznie sekretarzy stanu z Kancelarii Prezydenta oraz Kancelarii Prezesa Rady Ministrów, których można uznać za pomocników głowy państwa i szefa rządu, działających w ich imieniu. Udział takich osób uwarunkowany był posiadaną przez nich wiedzą specjalistyczną dotyczącą problematyki posiedzenia ${ }^{47}$, np. w posiedzeniu z 15 czerwca 2011 r. uczestniczyli Marszałek Sejmu Grzegorz Schetyna, Marszałek Senatu Bogdan Borusewicz i Sekretarz Stanu w Ministerstwie Spraw Zagranicznych Mikołaj Dowgielewicz ${ }^{48}$. Krystyna Leszczyńska trafnie wskazuje, że Konstytucja nie stanowi, iż Radę Gabinetową tworzy „wyłącznie” Rada Ministrów obradująca pod przewodnictwem prezydenta. Tym samym ustawa zasadnicza nie wyklucza uczestnictwa $\mathrm{w}$ jej posiedzeniach innych osób ${ }^{49}$. Warto też zauważyć, że Konstytucja nie określa, kto może uczestniczyć w posiedzeniach Rady Ministrów. O uczestnictwie osób spoza rządu decyduje przewodniczący tego gremium, jakim jest premier. Tym samym o uczestnictwie w posiedzeniu Rady Gabinetowej decyduje jej przewodniczący,

45 K. Leszczyńska, Rzady Rzeczypospolitej Polskiej..., s. 405, 409, 412.

46 Prof. Winczorek: Skład Rady Gabinetowej określa wprost Konstytucja, https://www.pb.pl/profwinczorek-sklad-rady-gabinetowej-okresla-wprost-konstytucja-462104 (dostęp: 20.08.2017).

47 B. Opaliński, Rada Gabinetowa w polskim systemie ustrojowym, „Przegląd Prawa Konstytucyjnego" 2011, nr 1, s. 119.

48 http://senat.gov.pl/diariusz/wydarzenia/art,1510,15-czerwca-2011-r-.html (dostęp: 20.08.2017).

49 K. Leszczyńska, Rządy Rzeczypospolitej Polskiej..., s. 402. 
czyli prezydent. Może on zaprosić osoby, których obecność okaże się przydatna w obradach oraz może wyrazić zgodę lub jej nie wyrazić na udział osób ewentualnie zaproponowanych przez premiera. Ponieważ Rada Gabinetowa ma służyć wymianie poglądów, uzyskaniu pewnych informacji i uzgodnieniu stanowisk, to ścisłe ograniczenie jej składu do członków rządu i głowy państwa byłoby zaprzeczeniem celu, dla którego została przewidziana.

Również przedmiotem sporu była kwestia jawności obrad Rady Gabinetowej, o co wnosił premier za pośrednictwem ministra Tomasza Arabskiego na jej posiedzeniu w dniu 14 stycznia $2008 \mathrm{r}$. Na tę propozycję zareagował sekretarz stanu w Kancelarii Prezydenta Maciej Łopiński pytaniem, czemu posiedzenia Rady Ministrów nie są jawne. Premier Donald Tusk odpowiedział, że wynika to z ustawy o Radzie Ministrów i Regulaminu Rady Ministrów ${ }^{50}$. Ponieważ Rada Gabinetowa to Rada Ministrów obradująca pod przewodnictwem prezydenta, to tym samym odnoszą się do niej regulacje dotyczące posiedzeń rządowych. Ponadto wprowadzenie jawności jej obrad przeczyłoby zasadzie swobodnej wymiany poglądów na jej posiedzeniach. Warto zauważyć, że na tym samym posiedzeniu premier bezskutecznie próbował objąć przewodnictwo, np. na pytania prezydenta chciał odpowiadać sam zamiast zapytanych ministrów, a zapytana minister Ewa Kopacz wręcz zwróciła się do premiera z pytaniem, czy może prezydentowi udzielić odpowiedzi.

Pozbawienie w obecnej Konstytucji premiera obowiązku informowania prezydenta o pracach rządu doprowadziło $\mathrm{w}$ warunkach kohabitacji do konfliktu między nimi. Premier Jerzy Buzek odmawiał prezydentowi Aleksandrowi Kwaśniewskiemu cotygodniowych spotkań, których chciał prezydent. Nie zgadzał się również na stałą obecność przedstawicieli głowy państwa w posiedzeniach rządu. Odpowiedzią na to było zwołanie Rady Gabinetowej. Jej koncepcja nie spotkała się jednak ze zrozumieniem polityków rządzącej koalicji. A. Kwaśniewski chciał, aby Rada spotykała się mniej więcej raz na dwa miesiące i aby dyskutowano na niej o sprawach najistotniejszych dla $\mathrm{kraju}^{51}$. W drodze kompromisu przyjęto, że przedstawiciele prezydenta będą zapraszani na ważniejsze posiedzenia rządu, a premier będzie się cyklicznie spotykał $\mathrm{z}$ głową państwa pomimo nieistnienia takiego prawnego obowiązku ${ }^{52}$.

Rada Gabinetowa w założeniu twórców Konstytucji miała być polem współpracy między dwoma organami władzy wykonawczej - prezydentem i rządem. Niejasność sformułowań ustawy zasadniczej doprowadziła do powstania sporu między nimi. Rząd dostrzegł, że prezydent chce uczynić z Rady Gabinetowej

50 Protokół posiedzenia Rady Gabinetowej w dniu 14 stycznia 2008 r. http://webcache.googleusercontent.com/search?q=cache:eVQQFnxli14J:doc.rmf.pl/rmf_fm/store/1582_protokol_14\%252001\%25202008.doc+\&cd=1\&hl=pl\&ct=clnk\&gl=pl (dostęp: 20.08.2017).

51 Prezydent sprawdza koalicję, 4 lutego 1998 r., Publicystyka. Opinie, https://archiwum.rp.pl/ artykul/157790-Prezydent-sprawdza-koalicje.html (dostęp: 20.08.2017).

52 S. Patyra, Pozycja ustrojowa..., s. 209. 
„mechanizm podporządkowujący Radę Ministrów w postaci rady prezydenckiej" ${ }^{3}$. Na zamiar prezydenta A. Kwaśniewskiego wskazuje treść projektu Regulaminu Rady Gabinetowej. Rząd zakwestionował jego ważność, gdyż regulamin został wydany bez kontrasygnaty premiera, a wśród prerogatyw prezydenta zwolnionych $\mathrm{z}$ kontrasygnaty premiera nie ma prawa do wydania tego regulaminu. Zdaniem urzędników Kancelarii Premiera regulamin był sprzeczny z Konstytucją i ustawą o organizacji i trybie pracy Rady Ministrów. Natomiast prawnicy prezydenta twierdzili, że jest to akt porządkowy i ma taką samą rangę, jak np. pismo o przeniesieniu na inne piętro prezydenckiego gabinetu. Część uprawnień przewidzianych w regulaminie jako przysługujące prezydentowi, Konstytucja i ustawa o Radzie Ministrów przyznaje szefowi rządu. Regulamin tworzył więc taką sytuację, w której głowa państwa przejmowała kompetencje premiera na czas posiedzeń Rady Gabinetowej ${ }^{54}$.

Zwoływanie posiedzeń Rady Gabinetowej w praktyce ustrojowej odbywało się dość rzadko. Najczęściej, bo aż dziesięć razy, skorzystał z tego prawa A. Kwaśniewski. Należy jednak pamiętać, że jak do tej pory jest to jedyny prezydent sprawujący urząd przez dwie kadencje. W okresie sprawowania przez niego urzędu głowy państwa ster rządu dzierżyło trzech premierów: Jerzy Buzek, Leszek Miller i Marek Belka. Czterokrotne zwołanie Rady Gabinetowej w warunkach kohabitacji miało miejsce, gdy premierem był J. Buzek. Pomimo poruszania na tych posiedzeniach spraw istotnych dla Polski żadne z nich nie zakończyło się przyjęciem wspólnego komunikatu i nie wpłynęło na treść decyzji podejmowanych przez Radę Ministrów oraz jej prezesa $\mathrm{a}^{55}$. W następstwie wyborów parlamentarnych z 2001 r. doszło do utworzenia rządu L. Millera. Polityczna bliskość i osobista znajomość szefa rządu i głowy państwa wpłynęły na charakter relacji między nimi. W tym okresie odbyło się sześć posiedzeń Rady Gabinetowej. Jedno z nich zostało zwołane na wniosek premiera z nadzieją na prezydenckie poparcie rządu w sporze z bankiem centralnym. Po posiedzeniach Rady Gabinetowej wydawano wspólne oświadczenia, często uzupełniane deklaracjami prezydenta o poparciu działalności rządu. Częstotliwość zwoływania posiedzeń Rady w okresie rządów L. Millera była przejawem rywalizacji prezydenta z szefem rządu o przywództwo $\mathrm{w}$ środowisku lewicowym. Ulegając presji swego środowiska, L. Miller w marcu 2004 r. zrezygnował z przywództwa w Sojuszu Lewicy Demokratycznej. Zdecydowanie osłabiło to jego pozycję polityczną i doprowadziło w dniu 2 maja 2004 r. do ustąpienia gabinetu. Nowym premierem został M. Belka. W okresie jego rządów Rada Gabinetowa nie została zwołana ani razu ${ }^{56}$. W tym czasie sto-

53 A. Dumała, Mechanizmy decyzyjne w demokracji konstytucyjnej, Lublin 1998, s. 46.

54 Ibidem, s. 46-47.

55 S. Patyra, Pozycja ustrojowa..., s. 201.

56 K. Leszczyńska, Rządy Rzeczypospolitej Polskiej..., s. 422. 
sunki między prezydentem a szefem rządu były bardzo dobre, $\mathrm{z}$ widoczną zależnością premiera od głowy państwa.

Przeprowadzone w 2005 r. wybory prezydenckie i parlamentarne przyniosły gruntowne zmiany na mapie politycznej Polski. Prezydentem został Lech Kaczyński, a rządy objęła koalicja Prawa i Sprawiedliwości, Ligi Polskich Rodzin i Samoobrony. W okresie prezydentury L. Kaczyńskiego było trzech premierów: Kazimierz Marcinkiewicz, Jarosław Kaczyński i - w warunkach kohabitacji - Donald Tusk. Prezydent czterokrotnie zwoływał posiedzenia Rady Gabinetowej, dwa razy gdy premierem był K. Marcinkiewicz. Potrzeba zintensyfikowania prac rządu zadecydowała o zmianie na stanowisku prezesa Rady Ministrów. W lipcu 2006 r. premierem został brat prezydenta, J. Kaczyński. W okresie istnienia jego gabinetu prezydent nie zwoływał Rady Gabinetowej - nie było takiej potrzeby. Serdeczne stosunki z bratem bliźniakiem zapewniały prezydentowi wystarczający dopływ potrzebnych informacji o pracach i zamierzeniach rządu. Rozpad koalicji rządzącej w 2007 r. doprowadził do skrócenia kadencji Sejmu. W następstwie przeprowadzonych wyborów parlamentarnych utworzony został rząd koalicji Platformy Obywatelskiej i Polskiego Stronnictwa Ludowego. Premierem został Donald Tusk. Prezydent wówczas dwukrotnie zwołał posiedzenie Rady Gabinetowej. Pierwsze z nich odbyło się w atmosferze wzajemnej nieufności i przy próbach premiera wpływania na przebieg posiedzenia. Natomiast drugie odbyło się w poprawnej atmosferze. Wprawdzie nie po raz pierwszy w III Rzeczypospolitej prezydent i rząd wywodziły się ze zwalczających się obozów politycznych, jednak stosunki między zantagonizowanymi obozami nigdy nie były tak wrogie. Niewątpliwie wzmacniały je osobiste animozje między prezydentem i premierem - D. Tusk ubiegał się o urząd prezydenta w 2005 r. i rywalizację przegrał.

W dniu 10 kwietnia 2010 r. zginął w katastrofie lotniczej pod Smoleńskiem prezydent L. Kaczyński. W takiej sytuacji obowiązki głowy państwa przejął Marszałek Sejmu Bronisław Komorowski, który parę miesięcy później został prezydentem. Premierami za jego kadencji byli Donald Tusk i Ewa Kopacz. Zmiana premiera nastąpiła we wrześniu 2014 r. w związku z objęciem przez D. Tuska w dniu 1 grudnia 2014 r. urzędu przewodniczącego Rady Europejskiej. B. Komorowski czterokrotnie zwoływał posiedzenia Rady Gabinetowej (pierwsze jeszcze jako Marszałek Sejmu wykonujący obowiązki prezydenta). Wszystkie posiedzenia zostały zwołane, gdy premierem był D. Tusk. Stosunki prezydenta z obydwoma szefami rządu układały się bezkonfliktowo.

Wybrany w 2015 r. na prezydenta Andrzej Duda do tej pory Rady Gabinetowej nie zwołał. Początkowo premierem została Beata Szydło, będąca wcześniej szefem kampanii wyborczej głowy państwa. Natomiast w 2017 r. prezesem Rady Ministrów został Mateusz Morawiecki. 
Tabela 1. Posiedzenia Rady Gabinetowej

\begin{tabular}{|c|c|c|c|c|}
\hline Lp. & Data & Prezydent & Premier & Tematyka posiedzenia \\
\hline 1 & 2 & 3 & 4 & 5 \\
\hline 1. & 27.01 .1998 & A. Kwaśniewski & J. Buzek & program rządu na 1998 r. \\
\hline 2. & 24.03.1998 & A. Kwaśniewski & J. Buzek & $\begin{array}{l}\text { przygotowanie Polski do } \\
\text { negocjacji i członkostwa w Unii } \\
\text { Europejskiej }\end{array}$ \\
\hline 3. & 23.02.1999 & A. Kwaśniewski & J. Buzek & $\begin{array}{l}\text { przygotowanie Polski do } \\
\text { przystąpienia do NATO, przebieg } \\
\text { wdrażania reform w państwie }\end{array}$ \\
\hline 4. & 4.09.2001 & A. Kwaśniewski & J. Buzek & stan finansów w państwie \\
\hline 5. & 21.02 .2002 & A. Kwaśniewski & L. Miller & $\begin{array}{l}\text { polityka gospodarcza, negocjacje } \\
\text { z Unią Europejską, przygotowania } \\
\text { do referendum, polityka } \\
\text { wschodnia }\end{array}$ \\
\hline 6. & 12.06 .2002 & A. Kwaśniewski & L. Miller & polityka pieniężna \\
\hline 7. & $\begin{array}{ll}6.11 \\
\text { i } 19.12 .2002\end{array}$ & A. Kwaśniewski & L. Miller & $\begin{array}{l}\text { strategia rozwoju Polski po } \\
\text { przystąpieniu do Unii Europejskiej }\end{array}$ \\
\hline 8. & 20.03.2003 & A. Kwaśniewski & L. Miller & $\begin{array}{l}\text { sytuacja międzynarodowa po } \\
\text { ataku wojsk USA na Irak, naprawa } \\
\text { finansów publicznych }\end{array}$ \\
\hline 9. & 6.11 .2003 & A. Kwaśniewski & L. Miller & $\begin{array}{l}\text { raport Unii Europejskiej } \\
\text { oceniający poziom przygotowań } \\
\text { polskiego prawa do regulacji } \\
\text { europejskich }\end{array}$ \\
\hline 10. & 24.03.2004 & A. Kwaśniewski & L. Miller & $\begin{array}{l}\text { stan przygotowań do członkostwa } \\
\text { Polski w Unii Europejskiej z dniem } \\
1 \text { maja } 2004 \text { r. }\end{array}$ \\
\hline 11. & 23.02 .2006 & L. Kaczyński & K. Marcinkiewicz & $\begin{array}{l}\text { Program rządu na } 2006 \text { r., } \\
\text { współpraca rządu z prezydentem } \\
\text { przy tworzeniu prawa }\end{array}$ \\
\hline 12. & 9.06 .2006 & L. Kaczyński & K. Marcinkiewicz & $\begin{array}{l}\text { sytuacja w służbie zdrowia, } \\
\text { polityka zagraniczna, } \\
\text { bezrobocie, zmiany w sposobie } \\
\text { opodatkowania twórców }\end{array}$ \\
\hline 13. & 14.01.2008 & L. Kaczyński & D. Tusk & sytuacja w służbie zdrowia \\
\hline 14. & 28.10 .2008 & L. Kaczyński & D. Tusk & przystąpienie Polski do strefy euro \\
\hline
\end{tabular}


Tabela 1 (cd.)

\begin{tabular}{|c|c|c|c|l|}
\hline 1 & 2 & 3 & 4 & \multicolumn{1}{|c|}{5} \\
\hline 15. & 10.06 .2010 & $\begin{array}{c}\text { B. Komorowski } \\
\text { (Marszałek Sejmu) }\end{array}$ & D. Tusk & sytuacja powodziowa w Polsce \\
\hline 16. & 15.06 .2011 & B. Komorowski & D. Tusk & $\begin{array}{l}\text { przygotowania do polskiego } \\
\text { przewodnictwa w Radzie Unii } \\
\text { Europejskiej }\end{array}$ \\
\hline 17. & 26.02 .2013 & B. Komorowski & D. Tusk & przystąpienie Polski do strefy euro \\
\hline 18. & 8.04 .2014 & B. Komorowski & D. Tusk & $\begin{array}{l}\text { wsparcie dla przeprowadzenia } \\
\text { reform na Ukrainie }\end{array}$ \\
\hline
\end{tabular}

Źródło: K. Leszczyńska, Rządy Rzeczypospolitej Polskiej (1989-2005). Skład, organizacja i tryb funkcjonowania, Toruń 2008, s. 402-420; http://www.prezydent.pl/archiwum-lecha-kaczynskiego/aktualnosci/rok-2006/art,150,134,posiedzenie-rady-gabinetowej.html; http://www. prezydent.pl/archiwum-lecha-kaczynskiego/aktualnosci/rok-2006/art,150,374,zatrzymac-mlodych-w-kraju.html; http://www.prezydent.pl/archiwum-lecha-kaczynskiego/aktualnosci/ rok-2008/art,148,998,euro-powinno-byc-przedmiotem-dyskusji.html; http://www.prezydent. pl/archiwum-lecha-kaczynskiego/aktualnosci/rok-2008/art,148,231,posiedzenie-rady-gabinetowej.html; http://www.prezydent.pl/archiwum-bronislawa-komorowskiego/aktualnosci/ wydarzenia/art,1367,posiedzenie-rady-gabinetowej.html; http://www.prezydent.pl/archiwum-bronislawa-komorowskiego/aktualnosci/zdjecia/galeria,629,17.html; http://www.prezydent. pl/archiwum-bronislawa-komorowskiego/aktualnosci/wydarzenia/art,2458, prezydent-zwolalposiedzenie-rady-gabinetowej.html; http://www.prezydent.pl/archiwum-bronislawa-komorowskiego/aktualnosci/wydarzenia/art,2862,rada-gabinetowa-potwierdza-wspolne-myslenieo-ukrainie.html (dostęp: 9.09.2017).

\section{Podsumowanie}

Zaliczenie w Konstytucji prezydenta i Rady Ministrów do organów władzy wykonawczej spowodowało konieczność stworzenia płaszczyzny współpracy między nimi. Wypracowując ją, twórcy Konstytucji sięgnęli do doświadczeń wynikających z wcześniejszych rozwiązań prawnych oraz praktyki ustrojowej. Przyjęte regulacje poszły w kierunku osłabienia pozycji prezydenta w odniesieniu do jego stosunków z rządem. W tym celu posłużono się instytucją Rady Gabinetowej składającej się z Rady Ministrów, zwoływanej przez prezydenta w sprawach „szczególnej wagi” i obradującej pod jego kierownictwem.

Wobec braku jakichkolwiek kompetencji nie można uznać Rady Gabinetowej za organ państwa. Jest ona tylko szczególną formą współpracy obu organów władzy wykonawczej. Konstytucja wyraźnie określa, że nie przysługują jej kompetencje Rady Ministrów. W przeciwnym razie prezydent mógłby okazać się nie tylko 
nominalnym, lecz także rzeczywistym szefem egzekutywy. Wprawdzie Konstytucja na ten temat milczy, ale oczywiste jest, że Radzie Gabinetowej nie przysługują kompetencje głowy państwa.

Niewątpliwie najczęstszym przedmiotem posiedzeń Rady Gabinetowej (a było ich osiemnaście) była problematyka związana z Unią Europejską (osiem, w tym dwie dotyczące wejścia do strefy euro). Ponadto przedmiotem obrad były sprawy gospodarcze, służby zdrowia i polityki zagranicznej, w tym wejścia Polski do NATO. Wydawać by się mogło, że posiedzenia Rady Gabinetowej nabierają głębokiego sensu, zwłaszcza w warunkach kohabitacji, jednak praktyka tego nie potwierdza. Rola tych posiedzeń ograniczała się jedynie do wymiany informacji, a w warunkach kohabitacji cechowała je wzajemna nieufność obu organów władzy wykonawczej. Prezydent A. Kwaśniewski podjął nawet próbę przejęcia kontroli nad Radą Ministrów. Dowodzi tego opracowany przez pracowników jego Kancelarii projekt Regulaminu Rady Gabinetowej. Strona rządowa jednak nie wyraziła na to zgody, zarzucając temu dokumentowi niekonstytucyjność i sprzeczność z ustawą o organizacji i trybie pracy Rady Ministrów. Posiedzenia Rady Gabinetowej służyły też doraźnym celom politycznym, czego najlepszym przykładem może być zwołanie jej posiedzenia przez Marszałka Sejmu pełniącego obowiązki głowy państwa i ubiegającego się o urząd prezydenta w okresie kampanii wyborczej, na dziesięć dni przed pierwszą turą wyborów.

Analiza obowiązujących przepisów konstytucyjnych dotyczących Rady Gabinetowej prowadzi do wniosku, że znacznie ograniczyły one pozycję prezydenta w stosunku do uregulowań z 1947, 1989 i 1992 r. Porównując Radę Gabinetową $\mathrm{z}$ analogicznymi rozwiązaniami obowiązującymi w krajach europejskich, należy uznać, że polski prezydent ma najmniejsze możliwości oddziaływania w niej na rząd i jego członków. Zarówno obowiązujące przepisy, jak i praktyka stawiają pod znakiem zapytania sens dalszego utrzymywania w obecnej postaci Rady Gabinetowej w Konstytucji. Aby zapewnić głowie państwa dopływ informacji na temat najważniejszych zamierzeń rządu, należałoby przywrócić obowiązek premiera informowania prezydenta o zamierzeniach gabinetu. Wiele oczywiście zależy także od kultury politycznej i osobistej prezydenta oraz szefa rządu.

\section{Santrauka}

\section{Kabinetų Taryba Lenkijoje}

Prezidento ir Ministrų Tarybos ịtraukimas Konstitucijoje ị vykdomosios valdžios organus privertè Konstitucijos kūrejjus sukurti šių organų bendradarbiavimo pamatus. Juos kurdami konstitucijos kūrejjai rèmèsi patirtimi iš praeities -ankstesniais teisiniais sprendimais ir 
politine praktika. Priimti įstatymai susilpnino prezidento poziciją vyriausybės atžvilgiu. Šiam tikslui pasinaudota Kabinetų Tarybos institucija susidedančia iš Ministrų Tarybos, sušaukiamos ir vadovaujamos prezidento „ypatingos svarbos“ klausimų atvejais.

Kadangi Kabinetų Taryba neturi jokių igaliojimų, negalima jos pripažinti valstybės organu. Kabinetų Taryba tèra ypatinga dviejų vykdomosios valdžios institucijų kooperacijos forma. Konstitucija aiškiai nustato, jog Kabinetų Tarybai nepriklauso jokie Ministrų Tarybos ịgaliojimai. Kitaip, prezidentą galima būtų pripažinti ne tik nominaliniu, bet ir faktiniu vykdomosios valdžios vadovu. Iš tiesų, Konstitucijoje apie tai nieko nèra sakoma, tačiau tai yra akivaizdu, jog Kabinetų Tarybai nepriklauso jokie Valstybès Vadovo igaliojimai.

Neabejotinai daugiausia kartų Kabinetų Tarybos posėdžiuose aptarinėjama tema (o jų buvo aštuoniolika) buvo su Europos Sąunga susijusi problematika (aštuonios, tame dvi susijusios su įstojimu i euro zoną). Be to, taip pat buvo aptarinejjami ekonominiai, sveikatos ir užsienio politikos klausimai, tame tarpe Lenkijos įstojimo į NATO klausimas. Atrodytų, jog Kabinetų Tarybos posėdžiai, juolab kohabitacijos sąlygomis, turi labai didelę svarbą. Visgi, praktika to nepatvirtina. Šie posėdžiai labiau vykdo keitimosi informacija funkciją, o kohabitacijos sąlygomis jiems būdingas abiejų vykdomosios valdžios organų tarpusavio nepasitikejjimas. Prezidentas A. Kwaśniewski netgi megino kontroliuoti Ministrų Taryba. Tai įrodo jo kanceliarijos darbuotojų paruoštas Kabinetų Tarybos reglamentas. Tačiau vyriausybė ji atmetė argumentuodama, jog projektas yra nekonstituciškas ir prieštarauja įstatymui dẻl Ministrų Tarybos darbo rěžimo ir organizavimo. Kabinetų Tarybos posėdžiai taip pat buvo naudojami ịprastiems politiniams tikslams. Geriausiu pavyzdžiu gali būti kuomet tuometinis Seimo Maršalka, vykdantis Valstybės Vadovo pareigas ir siekiantis tapti prezidentu rinkimų kampanijos metu, sušaukẻ Gabinetų Tarybos posėdị dešimt dienų prieš pirmaji rinkimų turą.

Galiojančių konstitucinių nuostatų, susijusių su Kabinetų Taryba analizė įrodo, jog jos žymiai susilpnino prezidento poziciją 1947, 1989 ir 1992 m. ̣̦statymų atžvilgiu. Lyginant Kabinetų Tarybą su kitais Europos šalyse egzistuojančiais šio organo analogais, galima pripažinti, jog Lenkijos prezidentas joje turi mažiausiai galimybių daryti įtaką vyriausybei ir jos ministrams. Tiek galiojantys įstatymai, tiek praktika, kelia abejonių dèl to ar verta tęsti Kabinetų Tarybos praktiką ir ar jos reglamentavimas Konstitucijoje turi būti tęsiamas. Kad užtikrinti tai jog prezidentas yra informuotas apie svarbiausius vyriausybès ketinimus, reikètų atstatyti Ministro Pirmininko pareigą informuoti prezidentą apie kabineto ketinimus. Žinoma, daug kas taip pat priklauso nuo politinès kultūros ir nuo asmeninès prezidento ir vyriausybès vadovo kultūros. Kaip pavyzdi galime paimti balandžio Konstitucijos galiojimo laikotarpiu vykdoma praktika kuomet Valstybès Vadovas su Ministru Pirmininku ir jo pavaduotoju rengè neoficialius savaitinius susitikimus. 


\section{Literatura}

Banaszak B., Konstytucja Rzeczypospolitej Polskiej. Komentarz, Warszawa 2009.

Banaszak B., Prawo konstytucyjne, Warszawa 2012.

Ciapała J., Prezydent w systemie ustrojowym Polski (1989-1991), Warszawa 1999.

Dudek D., Autorytet prezydenta a Konstytucja Rzeczypospolitej Polskiej, Lublin 2013.

Dumała A., Mechanizmy decyzyjne w demokracji konstytucyjnej, Lublin 1998.

Garlicki A., Józef Piłsudski 1867-1935, Warszawa 1990.

Glajcar R., Relacje prezydenta z Radą Ministrów, [w:] R. Glajcar, M. Migalski (red.), Prezydent w Polsce po 1989 r. Studium politologiczne, Warszawa 2006.

Górecki D., Polskie naczelne władze państwowe na uchodźstwie w latach 1939-1990, Warszawa 2002.

Górecki D., Pozycja ustrojowo-prawna Prezydenta Rzeczypospolitej i rządu w ustawie konstytucyjnej z 23 kwietnia 1935 roku, Łódź 1995.

Górecki D., Uwagi o charakterze Zgromadzenia Narodowego, [w:] M. Zubik, Minikomentarz dla maksiprofesora. Ksiega jubileuszowa Profesora Leszka Garlickiego, Warszawa 2017.

Jarosz Z., Rozwój ustroju państwowego Polski Ludowej w latach 1944-1952, [w:] Z. Jarosz, S. Zawadzki, Prawo konstytucyjne, Warszawa 1980.

Kierończyk P., Rada Gabinetowa, [w:] A. Szmyt (red.), Leksykon prawa konstytucyjnego, Warszawa 2010.

Leszczyńska K., Rządy Rzeczypospolitej Polskiej (1989-2005). Skład, organizacja i tryb funkcjonowania, Toruń 2008.

Mojak R., Instytucja Prezydenta RP w okresie przekształceń ustrojowych 1989-1992, Warszawa 1994.

Mojak R., Prezydent Rzeczypospolitej Polskiej, [w:] W. Skrzydło (red.), Prawo konstytucyjne, Lublin 1996.

Opaliński B., Rada Gabinetowa w polskim systemie ustrojowym, „Przegląd Prawa Konstytucyjnego" 2011, nr 1.

Opaliński B., Rozdzielenie kompetencji władzy wykonawczej między Prezydenta RP oraz Radę Ministrów na tle Konstytucji Rzeczypospolitej Polskiej z 1997 roku, Warszawa 2012.

Patyra S., Pozycja ustrojowa i funkcje prezesa Rady Ministrów - założenia konstytucyjne a praktyka, [w:] M. Grzybowski (red.), System rząów Rzeczypospolitej Polskiej. Założenia konstytucyjne a praktyka ustrojowa, Warszawa 2006.

Patyra S., Prawnoustrojowy status prezesa Rady Ministrów w świetle Konstytucji z 2 kwietnia 1997 r., Warszawa 2002.

Rozmaryn S., Polskie prawo państwowe, Warszawa 1951.

Sarnecki P., Komentarz do art. 141, [w:] L. Garlicki (red.), Konstytucja Rzeczypospolitej Polskiej. Komentarz, t. I, Warszawa 1999.

Sarnecki P., Prezydent Rzeczypospolitej Polskiej, Kraków 2000.

Skrzydło W., Instytucja Rady Gabinetowej w Polsce, [w:] A. Łopatka, A. Wróbel, S. Kiewlicz (red.), Państwo prawa, administracja, sądownictwo, Warszawa 1999. 
Słomka T., Prezydent Rzeczypospolitej po 1989 roku. Ujęcie porównawcze, Warszawa 2005. Szymczak T., Instytucja Prezydenta RP według noweli kwietniowej i w praktyce, „Państwo i Prawo" 1990, z. 10.

Szymczak T., Prezydent Rzeczypospolitej Polskiej, [w:] T. Szymczak (red.), Materiały pomocnicze do nauki prawa konstytucyjnego (1980-1991), Łódź 1992.

Witkowski Z., Prezydent Rzeczypospolitej Polskiej 1921-1935, Warszawa-Poznań-Torun 1987. Witkowski Z., Prezydent Rzeczypospolitej Polskiej, [w:] Z. Witkowski (red.), J. Galster, B. Gronowska, A. Bień-Kacała, A. Kustra, M. Rączka, K. Witkowska-Chrzczonowicz, I. Wróblewska, Prawo konstytucyjne, Toruń 2011.

\section{Akty prawne}

Konstytucja Federacji Rosyjskiej z 12 grudnia 1993 r., tłum. A. Kubik, Warszawa 2000.

Konstytucja Polskiej Rzeczypospolitej Ludowej z 22 lipca 1952 r., Dz.U. z 1952 r., nr 33, poz. 232 ze zm.

Konstytucja Republiki Białorusi z 15 marca 1996 r., https://en.wikisource.org/wiki/Constitution.of.the.Republic.of.Belarus (dostęp: 11.02.2014).

Konstytucja Republiki Chorwacji z 22 grudnia 1990 r., tłum. T. Wójcik, M. Petryńska, Warszawa 2007.

Konstytucja Republiki Czeskiej z 16 grudnia 1992 r., tłum. K. Skotnicki, Łódź 1994.

Konstytucja Republiki Finlandii z 11 czerwca 1999 r., tłum. J. Osiński, Warszawa 2003.

Konstytucja Republiki Francuskiej z 4 października 1958 r., tłum. W. Skrzydło, Warszawa 2000.

Konstytucja Republiki Islandii z 17 czerwca 1944 r., tłum. J. Osiński, Warszawa 2009.

Konstytucja Republiki Łotewskiej z 15 lutego 1922 r., tłum. L. Gołupiec, Warszawa 2001.

Konstytucja Republiki Portugalskiej z 2 kwietnia 1976 r., tłum. A. Wojtyczek-Bonnand, Warszawa 2000.

Konstytucja Republiki Słowackiej z 1 września 1992 r., tłum. K. Skotnicki, Warszawa 2003.

Konstytucja Rumunii z 21 listopada 1991 r., tłum. A. Cosma, Warszawa 1996.

Konstytucja Rzeczypospolitej Polskiej z 17 marca 1921 r., Dz.U. z 1921 r., nr 44, poz. 267 ze zm.

Konstytucja Rzeczypospolitej Polskiej z 7 kwietnia 1997 r., Dz.U. z 1997 r., nr 78, poz. 483 ze zm.

Ustawa konstytucyjna z 23 kwietnia 1935 r., Dz.U. z 1935 r., nr 30, poz. 227.

Ustawa konstytucyjna z 19 lutego 1947 r. o organizacji i zakresie działania najwyższych organów Rzeczypospolitej Polskiej, Dz.U. z 1947 r., nr 18, poz. 71 ze zm.

Ustawa konstytucyjna z 17 października 1992 r. o wzajemnych stosunkach między władzą ustawodawczą i wykonawczą Rzeczypospolitej Polskiej oraz o samorządzie terytorialnym, Dz.U. z 1992 r., nr 84, poz. 426 ze zm.

Ustawa o zmianie Konstytucji Polskiej Rzeczypospolitej Ludowej z 7 kwietnia 1989 r., Dz.U. z 1989 r., nr 19, poz. 101. 
Ustawa z 8 sierpnia 1996 r. o organizacji i trybie pracy Rady Ministrów oraz zakresie działania ministrów, miał obowiązek niezwłocznego zawiadomienia o tym członków rządu, Dz.U. z 1996 r., nr 106, poz. 492 ze zm.

Ustawa z 24 lipca 1999 r. o zmianie ustawy o działach administracji rządowej oraz niektórych innych ustaw, Dz.U. z 1999 r., nr 70, poz. 778.

\section{Strony internetowe}

http://senat.gov.pl/diariusz/wydarzenia/art,1510,15-czerwca-2011-r-html (dostęp: 20.08.2017). http://webcache.googleusercontent.com/search?q=cache:eVQQFnxIi14J:doc.rmf.pl/rmf_ fm/store/1582_protokol_14\%252001\%25202008.doc $+\& \mathrm{~cd}=1 \& \mathrm{hl}=\mathrm{pl} \& \mathrm{ct}=\mathrm{clnk} \& \mathrm{gl}=\mathrm{pl}$ (dostęp: 20.08.2017).

http://www.prezydent.pl/archiwum-bronislawa-komorowskiego/aktualnosci/wydarzenia/ art,1367,posiedzenie-rady-gabinetowej.html (dostęp: 9.09.2017).

http://www.prezydent.pl/archiwum-bronislawa-komorowskiego/aktualnosci/zdjecia/ galeria,629,17.html (dostęp: 9.09.2017).

http://www.prezydent.pl/archiwum-bronislawa-komorowskiego/aktualnosci/wydarzenia/ art,2458,prezydent-zwolal-posiedzenie-rady-gabinetowej.html (dostęp: 9.09.2017). http://www.prezydent.pl/archiwum-bronislawa-komorowskiego/aktualnosci/wydarzenia/ art,2862,rada-gabinetowa-potwierdza-wspolne-myslenie-o-ukrainie.html (dostęp:9.09.2017). http://www.prezydent.pl/archiwum-lecha-kaczynskiego/aktualnosci/rok-2006/ art,150,134,posiedzenie-rady-gabinetowej.html (dostęp: 9.09.2017).

http://www.prezydent.pl/archiwum-lecha-kaczynskiego/aktualnosci/rok-2006/ art,150,374,zatrzymac-mlodych-w-kraju.html (dostęp: 9.09.2017).

http://www.prezydent.pl/archiwum-lecha-kaczynskiego/aktualnosci/rok-2008/art,148, 998,euro-powinno-byc-przedmiotem-dyskusji.html (dostęp: 9.09.2017).

http://www.prezydent.pl/archiwum-lecha-kaczynskiego/aktualnosci/rok-2008/art,148, 231,posiedzenie-rady-gabinetowej.html (dostęp: 9.09.2017).

http://wyborcza.pl/1,75398,18540082,kopacz-prosi-dude-o-zwolanie-rady-gabinetowej-a-pis-proponuje.html (dostęp: 7.09.2017).

https://archiwum.rp.pl/artykul/157790-Prezydent-sprawdza-koalicje.html (dostęp: 20.08.2017). https://www.pb.pl/prof-winczorek-sklad-rady-gabinetowej-okresla-wprost-konstytucja462104 (dostęp: 20.08.2017). 